\title{
The rare case of a 20-year-old male with rapidly progressive primary angiitis of the CNS with a good outcome
}

Edith Graham, MD, Thomas Shoemaker, MD, Dusan Stefoski, MD, Marinos Kontzialis, MD, Anam Naumaan, MD, and Rajeev K. Garg, MD, MS

Neurol Neuroimmunol Neuroinflamm 2020;7:e793. doi:10.1212/NXI.0000000000000793

Rapidly progressive primary angiitis of the CNS (PACNS) is recognized as a clinical subtype of PACNS that is almost uniformly fatal. PACNS is usually characterized by subacute progression over several months. The most common symptoms are headaches and cognitive dysfunction, followed by focal neurologic deficits. ${ }^{1}$ Compared with this more indolent presentation, patients with rapidly progressive PACNS are more likely to present in coma with quadriparesis and MR imaging notable for bilateral infarcts. ${ }^{2}$ Various treatment combinations including high-dose corticosteroids, cyclophosphamide, azathioprine, methotrexate, rituximab, and plasma exchange have been described ${ }^{1,3}$; however, no good outcomes have been reported to date. The largest case series of 11 patients had only 1 survivor who at 14 months had a modified Rankin Scale (mRS) of 5 (bedridden, requiring constant nursing care). ${ }^{2}$ One other survivor of rapidly progressive PACNS had an mRS of 5 at the 3-month follow-up. ${ }^{4}$ We describe the treatment and outcome of a patient with rapidly progressive PACNS who returned to his premorbid baseline with an $\mathrm{mRS}$ of 0 .

\section{Case description}

A 20-year-old previously healthy man presented to a local hospital in acute coma. He had become progressively somnolent over the previous 8 hours. He had no prodromal illness, drug use, travel, or toxic exposures. His mother died suddenly in her forties of unknown causes. On arrival, he was unresponsive with pinpoint pupils and decorticate posturing to painful stimuli. Initial noncontrast head CT showed diffuse cerebral edema with hypodensities of the brainstem and thalami (figure 1, A-C). He was intubated for airway protection and transferred to our institution.

Noncontrast brain MRI 3 hours after admission revealed multifocal T2 FLAIR hyperintensities and effacement of the third and fourth ventricles (figure 1, D-F). Broad-spectrum antibiotics and dexamethasone were started for possible meningitis. Ten hours later, contrasted MRI showed worsening edema, new T2 FLAIR hyperintensities, and diffuse perivascular enhancement, suggestive of cerebral vasculitis (figure 1, G-J).

An external ventricular drain was placed for intracranial pressure monitoring and CSF sampling. This demonstrated 42 white blood cells ( $88 \%$ polymorphonuclear leukocytes), 8,000 red blood cells, glucose of 108 , and protein of 285 . Infectious studies were negative. The patient remained afebrile. On hospital day 1 , he was started on methylprednisolone $1 \mathrm{~g}$ daily and plasmapheresis every other day for 3 treatments. Urgent brain biopsy on hospital day 2 revealed small vessel necrotizing cerebral vasculitis (figure $1, \mathrm{~K}$ and $\mathrm{J}$ ). Rheumatologic evaluation was negative for systemic inflammatory disease. He was given cyclophosphamide $1,000 \mathrm{mg} / \mathrm{m}^{2}$ on days $6-8$. Hospital course was complicated by ventilator-associated pneumonia, thrombocytopenia, and cerebral salt wasting. The patient also developed malignant intracranial hypertension requiring treatment with
Correspondence

Dr. Graham

Edith_Graham@rush.edu

From the Department of Neurological Sciences (E.G., T.S., D.S., R.K.G.), Department of Radiology (M.K.) and Department of Pathology (A.N.), Rush University Medical Center, Chicago, IL.

Go to Neurology.org/NN for full disclosures. Funding information is provided the end of the article.

The article processing charge was funded by the authors.

This is an open access article distributed under the terms of the Creative Commons Attribution-NonCommercial-NoDerivatives License 4.0 (CC BY-NC-ND), which permits downloading and sharing the work provided it is properly cited. The work cannot be changed in any way or used commercially without permission from the journal. 


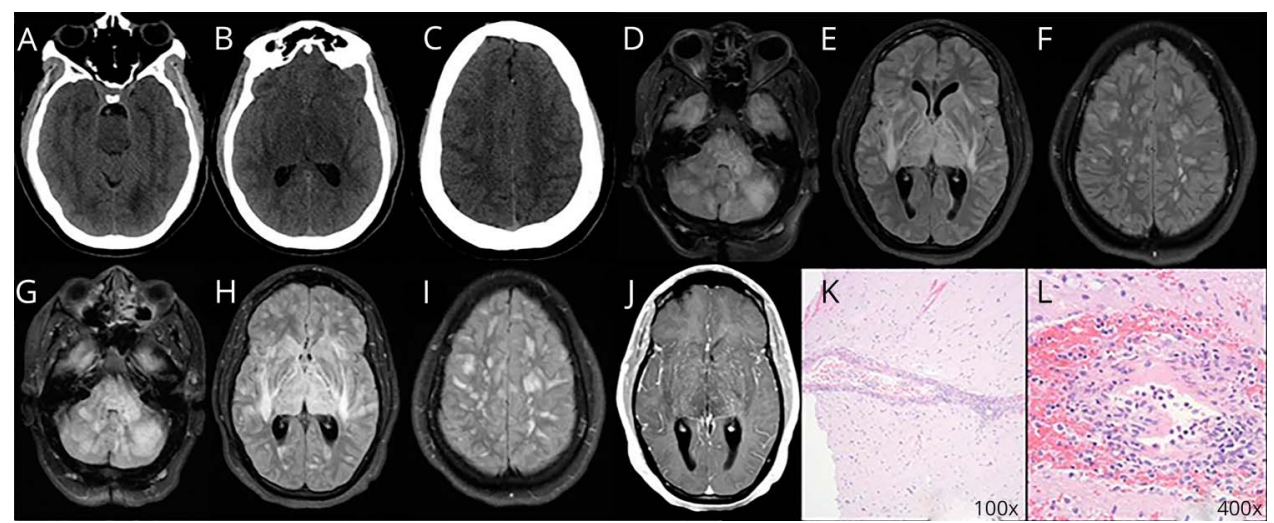

Initial head $\mathrm{CT}$ noncontrast showed diffuse cerebral edema, effacement of the ambient cistern, and hypodensities of the pons, midbrain, and thalami (A-C). Noncontrast brain MR 5 hours later with multifocal, supratentorial, and infratentorial T2 FLAIR hyperintensities and diffuse cerebra edema (D-F). Ten hours later, contrasted brain MRI showed worsening cerebral edema, new T2 FLAIR hyperintensities (G-I), and diffuse perivascular enhancement suggestive of cerebral vasculitis (J). Brain tissue contains small vessel perivascular dense lymphohistiocytic infiltrate $(K)$. Higher power view of the vessel wall shows fibrinoid necrosis and a mixed inflammatory infiltrate consisting of neutrophils, lymphocytes, and histiocytes (L).

hyperosmolar therapy on days 1 through 22, pentobarbital and methohexital coma on days 3-17, and hypothermia protocol on days 4-10 (figure e-1, links.lww.com/NXI/A269).

Repeat contrasted MRI brain on day 22 showed decreasing T2 FLAIR hyperintensities and resolution of perivascular enhancement. He required tracheostomy and percutaneous gastrostomy. He received 1 dose of rituximab 1,000 mg on hospital day 30 and was discharged to a long-term acute care facility on day 31. On discharge, he was awake and texting on his cell phone. He returned to work at 5 months and remains with an mRS of 0 at 14 months.

\section{Discussion}

To our knowledge, this is the first case described in the literature of a patient with rapidly progressive PACNS who survived with good outcome. Our report demonstrates that prompt diagnosis, aggressive neurocritical intervention, and early immunosuppressant therapy can lead to a good outcome in rapidly progressive PACNS.

The terminology to describe rapidly progressive PACNS is not consistent in the literature. Terms such as "fulminant" and "catastrophic" are used interchangeably to describe this subset of PACNS. "Necrotizing" has also been used, but has been reserved mainly to describe the histopathology. ${ }^{5}$ Our patient's biopsy showed a necrotizing pattern. Some studies have suggested that necrotizing and granulomatous patterns are associated with worse outcomes ${ }^{2}$; however, this is controversial because these patterns may also be seen in less aggressive PACNS. ${ }^{6}$ A lymphocytic pattern has been associated with a better prognosis in $\mathrm{PACNS}^{3,5}$; however, there has also been a case of rapidly progressive PACNS with lymphocytic pattern. ${ }^{7}$ Therefore, it is difficult to draw conclusions on prognosis based on histopathology alone.

We recommend a high index of suspicion for rapidly progressive PACNS in patients with progression to coma and quadriparesis in less than 24 hours and imaging evidence of multiple bilateral cerebral infarctions. Future research into optimal diagnostic and therapeutic strategies may lead to more patients with a favorable outcome in this disease.

\section{Study funding}

No targeted funding.

\section{Disclosure}

E. Graham reports no financial disclosures. T. Shoemaker receives royalties from Genentech. D. Stefoski reports no financial disclosures. M. Kontzialis receives royalties from Elsevier. A. Naumaan and R. K. Garg report no financial disclosures. Go to Neurology.org/NN for full disclosures.

\section{Publication history}

Received by Neurology: Neuroimmunology \& Neuroinflammation April 22, 2020. Accepted in final form May 12, 2020.

Appendix Authors

\begin{tabular}{lll}
\hline Author & Institution & Contribution \\
\hline $\begin{array}{l}\text { Edith } \\
\text { Graham, MD }\end{array}$ & $\begin{array}{l}\text { Rush University Medical } \\
\text { Center, Chicago, IL }\end{array}$ & Primary author \\
\hline $\begin{array}{l}\text { Thomas } \\
\text { Shoemaker, } \\
\text { MD }\end{array}$ & $\begin{array}{l}\text { Rush University Medical } \\
\text { Center, Chicago, IL }\end{array}$ & $\begin{array}{l}\text { Contributed to case } \\
\text { management and reviewed } \\
\text { the article }\end{array}$ \\
\hline $\begin{array}{l}\text { Dusan } \\
\text { Stefoski, MD }\end{array}$ & $\begin{array}{l}\text { Rush University Medical } \\
\text { Center, Chicago, IL }\end{array}$ & $\begin{array}{l}\text { Contributed to case } \\
\text { management and reviewed } \\
\text { the article }\end{array}$ \\
\hline $\begin{array}{l}\text { Marinos } \\
\text { Kontzialis, MS }\end{array}$ & $\begin{array}{l}\text { Rush University Medical } \\
\text { Center, Chicago, IL }\end{array}$ & $\begin{array}{l}\text { Reviewed the imaging and } \\
\text { article }\end{array}$ \\
\hline $\begin{array}{l}\text { Anam } \\
\text { Naumaan, } \\
\text { MD }\end{array}$ & $\begin{array}{l}\text { Rush University Medical } \\
\text { Center, Chicago, IL }\end{array}$ & $\begin{array}{l}\text { Obtained pathology images } \\
\text { and reviewed the article }\end{array}$ \\
\hline $\begin{array}{l}\text { Rajeev K } \\
\text { Garg, MD, MS }\end{array}$ & $\begin{array}{l}\text { Rush University Medical } \\
\text { Center, Chicago, IL }\end{array}$ & $\begin{array}{l}\text { Project advisor and edited } \\
\text { the manuscript }\end{array}$ \\
\hline
\end{tabular}




\section{References}

1. Beuker C, Schmidt A, Strunk D, et al. Primary angiitis of the central nervous system: diagnosis and treatment. Ther Adv Neurol Disord 2018;11:1-16.

2. Salvarani C, Brown $\mathrm{RD} \mathrm{Jr}$, Calamia KT, et al. Rapidly progressive primary central nervous system vasculitis. Rheumatology (Oxford) 2011;50:349-358.

3. de Boysson H, Zuber M, Naggara O, et al; French Vasculitis Study Group and the French NeuroVascular Society. Primary angiitis of the central nervous system: description of the first fifty-two adults enrolled in the French cohort of patients with primary vasculitis of the central nervous system. Arthritis Rheumatol 2014;66: 1315-1326.
4. Safouris A, Stricker J, Michotte A, Voumvourakis K, Gazagnes MD, Tsivgoulis G. Biopsy proven fulminant primary angiitis of the central nervous system with normal arteriography: a challenging diagnosis of recurrent ischemic strokes. Neurol Sci 2014;35:135-137.

5. Salvarani C, Brown RD Jr, Christianson T, et al. An update of the Mayo Clinic cohort of patients with adult primary central nervous system vasculitis: description of 163 patients. Medicine (Baltimore) 2015;94:e738.

6. Sundaram S, Menon D, Khatri P, et al. Primary angiitis of the central nervous system: clinical profiles and outcomes of 45 patients. Neurol India 2019;67:105-112.

7. Spence S, Ng D, Casault C. Atypical presentation of fulminant primary central nervous system angiitis. J Neuroimmunol 2019;330:1-4. 


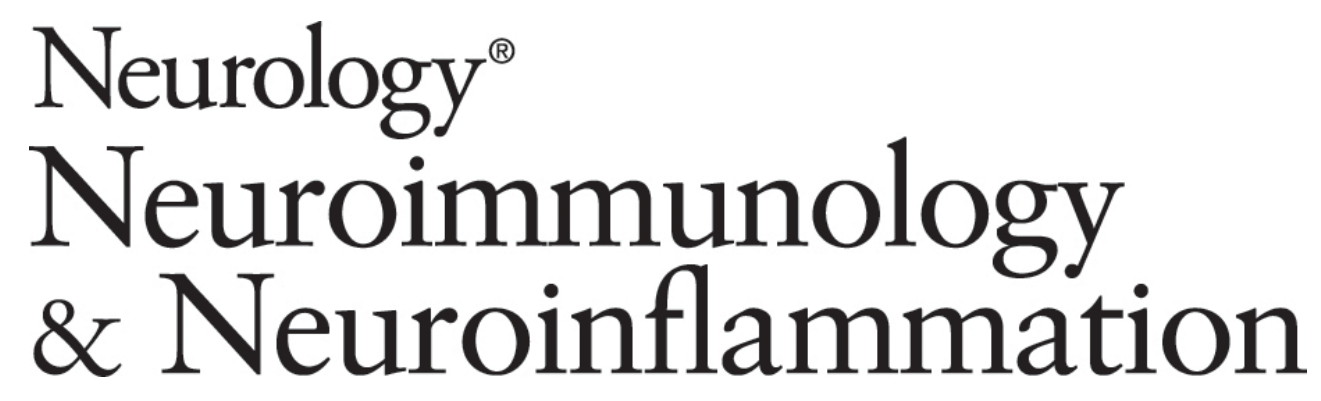

The rare case of a 20-year-old male with rapidly progressive primary angiitis of the CNS with a good outcome

Edith Graham, Thomas Shoemaker, Dusan Stefoski, et al.

Neurol Neuroimmunol Neuroinflamm 2020;7;

DOI 10.1212/NXI.0000000000000793

This information is current as of June 9, 2020

Neurol Neuroimmunol Neuroinflamm is an official journal of the American Academy of Neurology.

Published since April 2014, it is an open-access, online-only, continuous publication journal. Copyright

Copyright $\odot 2020$ The Author(s). Published by Wolters Kluwer Health, Inc. on behalf of the American

Academy of Neurology.. All rights reserved. Online ISSN: 2332-7812.

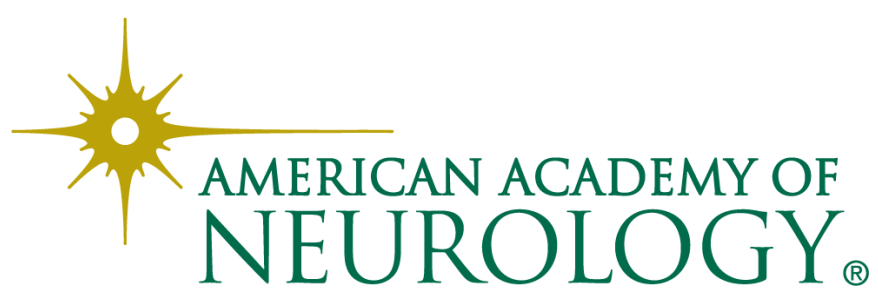




\section{Updated Information \& Services}

References

Subspecialty Collections

Permissions \& Licensing

Reprints including high resolution figures, can be found at:

http://nn.neurology.org/content/7/5/e793.full.html

This article cites 7 articles, 0 of which you can access for free at: http://nn.neurology.org/content/7/5/e793.full.html\#\#ref-list-1

This article, along with others on similar topics, appears in the following collection(s):

\section{Autoimmune diseases}

http://nn.neurology.org//cgi/collection/autoimmune_diseases

\section{Critical care}

http://nn.neurology.org//cgi/collection/critical_care

Other cerebrovascular disease/ Stroke

http://nn.neurology.org//cgi/collection/other_cerebrovascular_disease_ stroke

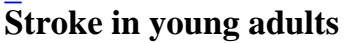

http://nn.neurology.org//cgi/collection/stroke_in_young_adults Vasculitis

http://nn.neurology.org//cgi/collection/vasculitis

Information about reproducing this article in parts (figures,tables) or in its entirety can be found online at:

http://nn.neurology.org/misc/about.xhtml\#permissions

Information about ordering reprints can be found online:

http://nn.neurology.org/misc/addir.xhtml\#reprintsus

Neurol Neuroimmunol Neuroinflamm is an official journal of the American Academy of Neurology.

Published since April 2014, it is an open-access, online-only, continuous publication journal. Copyright

Copyright $\odot 2020$ The Author(s). Published by Wolters Kluwer Health, Inc. on behalf of the American Academy of Neurology.. All rights reserved. Online ISSN: 2332-7812.

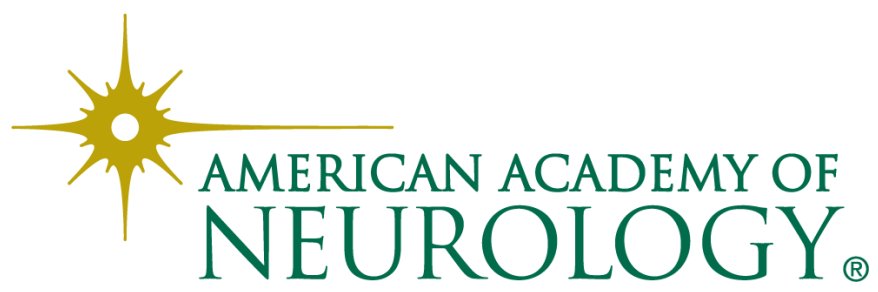

